\title{
Editorial for AIChE Journal 2020 Futures Issue
}

\author{
Michael Harold ${ }^{1}$ \\ ${ }^{1}$ University of Houston
}

October 21, 2020

\section{Editorial - The third "Futures" issue}

This month's volume of AIChE Journal is the third "Futures" issue. I think now we've established a tradition. This is my favorite issue each year.

Each year we invite a group of early career researchers to contribute their pioneering works. I have sought the input of the AIChE Journal editorial team and consulting editorial board to identify contributors. The criterion is that the prospective author be seven or less years removed from her or his initial appointment as an academic, industrial, or national lab researcher.

During the publication year we have a session at the Annual AIChE meeting where several of the authors have the opportunity to present their research. (This being the year of COVID-19, these presentations will unfortunately be virtual.)

The "Futures" issue parallels the annual "Founders" issue; while the "Founders" issue celebrates the scholarly legacies of the greats from our profession, the "Futures" issue recognizes the research of emerging scholars.

I hope that you enjoy this third installment of the "Futures" series.

On behalf of the AIChE Journal editorial team, we look forward to your input and suggestions. As always, thanks for your support of

AIChE Journal.

Yours sincerely,

\section{Hosted file}

image1.emf available at https://authorea.com/users/368934/articles/487936-editorial-for-

aiche-journal-2020-futures-issue

Mike Harold, Editor-in-Chief 